\title{
Ectopic Expression of WUSCHEL (AtWUS) Gene Alters Plant Growth and Development in Rice
}

\author{
Thiveyarajan Victorathisayam, Ganapathi Sridevi* \\ Department of Plant Biotechnology, Madurai Kamaraj University, Madurai, India \\ Email address: \\ athisayam.victor@gmail.com (T. Victorathisayam), sridevi.biotech@mkuniversity.org (G. Sridevi), \\ srideviganapathi@yahoo.com (G. Sridevi) \\ *Corresponding author
}

\section{To cite this article:}

Thiveyarajan Victorathisayam, Ganapathi Sridevi. Ectopic Expression of WUSCHEL (AtWUS) Gene Alters Plant Growth and Development in Rice. Plant. Vol. 8, No. 3, 2020, pp. 43-53. doi: 10.11648/j.plant.20200803.11

Received: July 4, 2020; Accepted: July 25, 2020; Published: August 25, 2020

\begin{abstract}
Developmental genes (DG)/ morphogenic genes are involved in enhancing the transformation and regeneration of plants. One such DG is the WUSCHEL (WUS) gene, a homeodomain transcription factor, and is involved in the stem cell maintenance of shoot apical meristem (SAM). In dicots, ectopic expression of WUS induced the embryogenic calli formation and organogenesis. On the other, WUS overexpression resulted in pleiotropic effects in most of the monocots. Also, very few dicots failed to regenerate due to the overexpression of WUS. In our study, the $35 \mathrm{~S}$ driven WUS (AtWUS) gene expressing transgenic rice plants were generated. All the transgenic plants with the WUS (W) gene along with the vector (V) and untransformed $(\mathrm{U})$ lines were confirmed by detailed Southern analyses. The single-copy W and V plants with complete T-DNA were taken for detailed analyses. The $\mathrm{W}$ plants exhibited few phenotypic changes such as thick stem, reduction in the internode length, enclosed panicle, unopen flower, pale yellow colour of the anther, and loss of viable pollens compared to the $\mathrm{U}$ and $\mathrm{V}$ plants. Interestingly, crown root formation and small vein formation in the leaves were detected in the $\mathrm{W}$ plants. The expression of the WUS gene was confirmed by RT-PCR analysis in the W plants. The seeds from the hemizygous plants showed enhanced embryogenic calli formation and attained early regeneration compared to $U$ and $V$ plants thereby confirming the role of the WUS gene in embryogenesis and regeneration.
\end{abstract}

Keywords: WUSCHEL, Embryogenic Calli, Regeneration, Pleiotropic Effects, Organogenesis

\section{Introduction}

Developmental genes (DGs) also known as morphogenic genes are involved in plant transformation and regeneration through a variety of mechanisms such as embryogenesis and organogenesis [1]. Somatic embryogenesis and plant regeneration can be increased by the exogenous supply of hormones which would reprogramme the fate of the cell [2]. Previous reports revealed that many morphogenic/related genes /transcription factors (TF) reprogramme the cell fate to increase the transformation [3] and regeneration efficiency $[4,5]$ in plants. Many TFs are involved in each stage of embryogenesis such as callus induction, embryogenic calli formation $[6,7]$. Similarly, many TFs play a major role in plant regeneration and determine the fate of the cell under epigenetic [8-11], hormone-induced [12], or stress-induced conditions $[13,14]$. Among the different categories of the
TFs, the TFs encoded by homeobox genes play a major role in regulating plant development and determining the cell fate. These homeobox TFs have at least 2 domains: one for recognition and binding, and the other for organizing additional proteins involved in transcription. The WUSCHEL- related homeobox (WOX) gene family belongs to the homeobox TF superfamily. All the members in this family possess homeodomain (HD) with 60-66 amino acid residues and bind DNA through a helix-turn-helix (HTH) structure $[15,16]$. The HTH domain of the WUS gene possesses a nuclear localization signal (NLS) that has a strong binding affinity towards DNA and regulates the gene expression precisely. The WUS gene that encodes an HD TF is required for shoot apical meristem (SAM) and contributes to plant development that includes embryo patterning, stem cell maintenance, and organ formation. In Arabidopsis, the embryonic cell identity was maintained by the WUS gene 
$[17,18]$. Upon mutation of the wus gene, Arabidopsis failed to maintain shoot and floral meristem (FM) [19, 20] while there is an increase in meristematic cells rather than differentiation. WUS plays a role in the maintenance of stem cells not only in SAM but also in FM [21]. In rice, the WUS orthologue is called $O s W U S$ which plays a major role in the tillering and fertility of rice [22]. The indica rice variety has 12 WOX genes and japonica has 17 WOX genes. Other orthologues of WUS are MONOCULM 3 (MOC3) [23] and TILLERS ABSENT1 (TAB1) [24-26]. These orthologues differ in their functions like tillering, fertility, tiller bud formation, and axillary meristem formation. The undifferentiated state of SAM in Oryza sativa, Arabidopsis thaliana, Antirrhinum majus, and Petunia was maintained by the homeobox gene, OsWOX4 [27], WUS (WUSCHEL) [20], ROA (ROSULATA) [28] and TER (TERMINATOR) [29], respectively.

Kamiya et al. [30] isolated the $Q H B$ gene, a WUS type homeobox gene to study the stem cell maintenance in root apical meristem (RAM). As there is no homology for the AtWUS gene in rice, they used rice actin driven AtWUS gene for comparison studies. The overexpression of $Q H B$ and $W U S$ gene in rice revealed defects in crown root formation. The seedlings showed severe dwarfism with malformed leaves. The morphology of leaves and the roots were interrelated. The defects in the crown root formation tend to result in the formation of malformed leaves. These results confirmed that the WUS-type homeobox gene is involved in the maintenance of the stem cells in RAM, which is similar to the mechanism in SAM. In the case of tobacco, the overexpression of the AtWUS gene affected the seedling stage, and later ectopic outgrowth was found in laminas, stem, and leaf axils. At the flowering stage, no outgrowth was seen and resulted in shorter stigma, style, and filament compared to the wild type. Yet the ectopic organogenesis was obtained by AtWUS in tobacco transformants and played a role in leaf development. They provided the evidence that WUS gene played a role in organ formation apart from stem cell maintenance. The ectopic expression of inducible (estradiol) promoter-driven AtWUS gene in Capsicum chinense [31], and Picea glauca [32] resulted in embryogenic calli formation and increased seedling growth. Similar to an inducible promoter, constitutive (35S) expression of the AtWUS gene also increased the somatic embryo formation in Coffea canephora [33]. Many of the cotton cultivars were difficult to regenerate due to the failure of embryogenic calli formation [34]. The 35S driven AtWUS expression in Gossypium hirsutum enhanced the embryogenic calli formation. Of the three different stages of in vitro regeneration, the WUS gene expression was found to be in the first stage only. The calli size increased in stages 2 and 3 . The increased WUS expression turned the calli greenish and the plants failed to regenerate as a result of WUS overexpression [35]. In recalcitrant cotton variety CRI12, the embryogenic calli differentiation was obtained by overexpression of the $35 \mathrm{~S}$ promoter-driven AtWUS gene. Also, the WUS gene enhanced the expression of LEC1 (LEAFY COTYLEDON), LEC2, and FUS3 (FUSCA3) during somatic embryogenesis [36]. LEC1, $L E C 2$, and $F U S 3$ play a major role in embryogenic calli formation $[37,38]$. The soybean TF GmWOX18 expression increased the clustered buds in genetic transformation and increased regeneration [39]. Overexpression of the Chrysanthemum WUS gene in A. thaliana led to the formation of polysymmetric flowers rather than monosymmetric flowers.

Apart from single gene expression, a combination of DGs would help in enhancing the transformation and regeneration in plants [1]. Combined expression of maize $W U S$ and $B A B Y$ $B O O M(B B M)$ genes increased the monocot transformation under weak and strong promoter, respectively [3]. Upon constitutive expression in maize, the transformation efficiency increased and had some pleiotropic effects. The expression pattern of $B B M$ and $W U S$ genes were found to be enhanced at different developmental stages and also at specific tissues. When maize immature embryos were used as explants more somatic embryos were formed and the regeneration increased rapidly. Under auxin-induced promoter, the plants were healthier compared to noninducible promoter expression [40, 41]. Meanwhile, Mookan et al. [42] also described that the combined expression of maize $B B M$ and WUS2 genes using cre-lox technology increased the monocot transformation in recalcitrant sorghum and maize inbred lines and obtained fertile plants. Coexpression of $W O X$ genes (WOX2 with WOX8/WOX9) also induced the genes involved in the regeneration of tobacco and increased the shoot like structures in tissue culture without the external supply of cytokinin [43].

Until now all these previous studies involved the controlled expression of DGs either by transient, inducible, or tissue-specific expression, and excision of DGs using crelox mechanism [5]. Upon constitutive expression of the AtWUS gene, the transgenic plants displayed pleiotropic effects. The rice actin promoter-driven AtWUS gene affected the rice seedlings and resulted in dwarfism along with malformed leaves and the absence of crown root formation. In this study, more emphasis was given to explore the role of the WUS type homeobox gene, $Q H B$ in RAM [30]. The expression of the AtWUS gene under the 35S promoter in Arabidopsis induced aberrant cell division at the calli stage but failed to regenerate [36]. In other plants, the $35 \mathrm{~S}$ promoter-driven WUS gene enhanced the embryogenic calli formation. However, the role of AtWUS gene expression towards embryogenic calli formation and regeneration needs to be studied in detail to improve the transformation of recalcitrant cultivars. Towards that, we overexpressed $35 \mathrm{~S}$ driven AtWUS gene in rice and generated transgenic plants. These transgenic plants were confirmed by detailed Southern analyses. The transgenic plants exhibited some morphological differences compared to control plants. The seeds from hemizygous single copy plants were evaluated for the role of embryogenic calli formation and regeneration.

\section{Materials and Methods}

\subsection{Binary Vector and Rice Transformation}

The WUSCHEL (AtWUS) gene was taken as a SpeI/XhoI 
fragment $(1.1 \mathrm{~kb})$ from pER10 (purchased from Dr. Nam-Hai Chua, Rockefeller University, USA) and cloned into $X b a \mathrm{I} / X h o \mathrm{I}$ site in between $35 \mathrm{~S}$ promoter and polyA in pRT100. The resultant clone was designated as pMG1. The whole cassette was taken as a SphI fragment and treated with the Klenow enzyme. The Klenow treated fragment was cloned into the SmaI site of pCAMBIA1301 and the resultant clone was designated as pMG2 (Figure 1). The binary vector, pMG2, and pCAMBIA1301 were mobilized into Agrobacterium tumefaciens strain LBA4404 (pSB1) by triparental mating individually and confirmed by Southern analyses. Rice seeds (Oryza sativa cv IET10364) were surface sterilized [44] and placed in the callus induction medium. The 21-day-old scutellum derived embryogenic rice calli were used for transformation and pre-incubated for 3 days. Rice transformation was performed using the Agrobacterium strain LBA4404 (pSB1, pMG2) and LBA4404 (pSB1, pCAMBIA1301), with appropriate controls. After 3 days of co-cultivation, the infected calli were placed on the selection medium harbouring $50 \mathrm{mg} / \mathrm{l}$ hygromycin and $250 \mathrm{mg} / \mathrm{l}$ cefotaxime for 14 days. Subsequently, after two rounds of selection (21 days for each selection), the calli were placed on to the regeneration medium containing $40 \mathrm{mg} / \mathrm{l}$ hygromycin and $250 \mathrm{mg} / \mathrm{l}$ cefotaxime [45]. GUS staining [46] was performed with the calli and leaves to identify the putative transformants. The regenerated plantlets were acclimatized to soil and maintained in the transgenic greenhouse till maturity.

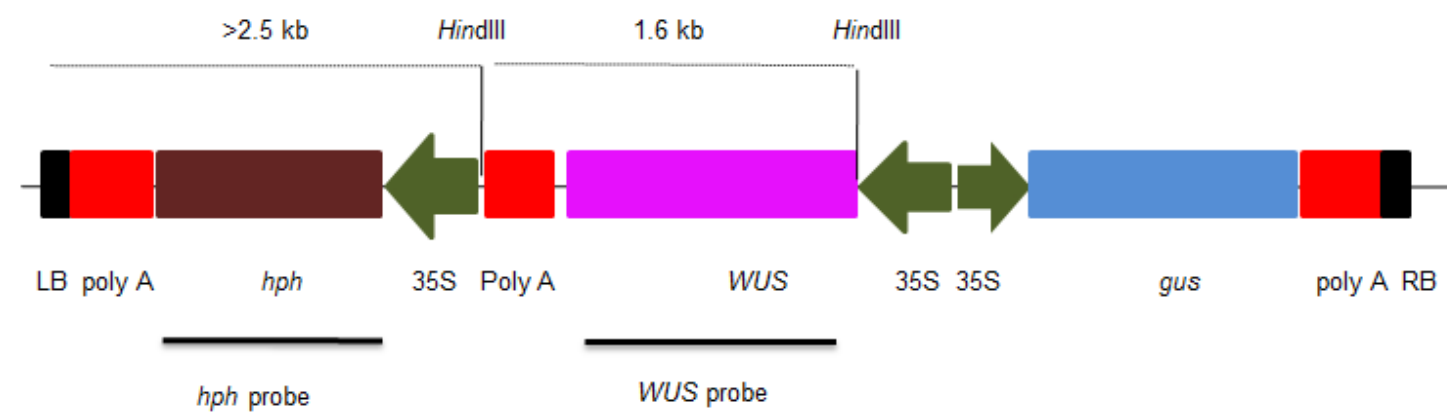

Figure 1. Linear map of pMG2. The T-DNA portion of the binary plasmid pMG2 harbours p35S-hph gene in the HindIII site of pCAMBIA1301. Left border junction fragments $(>2.5 \mathrm{~kb})$ generated by HindIII digestion are indicated by a line. $35 S-$ CaMV35S promoter, LB - Left border, hph - hygromycin

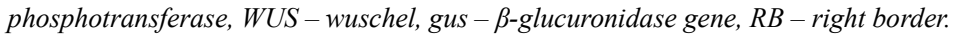

\subsection{PCR Analyses}

Genomic DNA from untransformed (U), vector (V), and WUS (W) transformed plants were extracted using the CTAB method [47] and quantified by fluorimeter [48]. Genomic DNA (100 ng) was used as a template and PCR analysis was performed using gus, hph, and WUS gene-specific primers. The gus fragment $(0.5 \mathrm{~kb})$ was amplified using the primers: (5' TATCAGCGCGAAGTCTTTATACC $\left.3^{\prime}\right)$ and (5' CAGTTGCAACCACCTGTTGAT 3') with the following condition $\left[94^{\circ} \mathrm{C}\right.$ for $2 \mathrm{~min}$ followed by 30 cycles $\left(94^{\circ} \mathrm{C}\right.$ for 30 sec, $58^{\circ} \mathrm{C}$ for $40 \mathrm{sec}, 72^{\circ} \mathrm{C}$ for $45 \mathrm{sec}$ ) and final extension with $72^{\circ} \mathrm{C}$ for $\left.6 \mathrm{~min}\right]$. The $h p h$ fragment $(1.1 \mathrm{~kb})$ was amplified using the primers: (5' AAAGCCTGAACTCACCGC 3') and (5' GGTTTCCACTATCGGCGAG 3') with the following conditions $\left[94^{\circ} \mathrm{C}\right.$ for $1 \mathrm{~min}$ followed by 30 cycles $\left(94^{\circ} \mathrm{C}\right.$ for 1 $\min , 56^{\circ} \mathrm{C}$ for $1 \mathrm{~min}, 72^{\circ} \mathrm{C}$ for $1 \mathrm{~min}$ ) and final extension with $72^{\circ} \mathrm{C}$ for $\left.6 \mathrm{~min}\right]$. The WUS fragment $(0.83 \mathrm{~kb})$ was amplified with the primers: (5' CATCAAGCCGACCAAGAAAGC 3') and (5' TAGCTCAAGAGAAGCGCAAGG 3') with the following conditions $\left[94^{\circ} \mathrm{C}\right.$ for $1 \mathrm{~min}$ followed by 30 cycles $\left(94^{\circ} \mathrm{C}\right.$ for $40 \mathrm{sec}, 60^{\circ} \mathrm{C}$ for $30 \mathrm{sec}, 72^{\circ} \mathrm{C}$ for $\left.1 \mathrm{~min}\right)$ and final extension with $72^{\circ} \mathrm{C}$ for $5 \mathrm{~min}$ ].

\subsection{Southern Blot Analyses}

Five micrograms of DNA from $\mathrm{U}, \mathrm{V}$, and $\mathrm{W}$ plants were digested with the enzyme HindIII and electrophoresed. The $h p h$ and WUS probes were labeled with the digoxigenin and non-radioactive Southern [49] was performed following the manufacturer's instruction (Roche, Germany).

\subsection{Segregation Analyses}

The $\mathrm{T}_{0}$ seeds were surface sterilized and placed in half MS medium [50] for 3 days. After three days the germinated seedlings were transferred to MS medium harbouring $50 \mathrm{mg} / \mathrm{l}$ hygromycin and scored for hygromycin resistance. A Chi-square test was performed to validate statistically hygromycin sensitive and resistant plantlets. Further GUS staining was used to identify the zygosity in $\mathrm{T}_{1}$ and $\mathrm{T}_{2}$ lines.

\subsection{Leaf Development and Pollen Staining}

Leaf development was studied at regular intervals in the U, $\mathrm{V}$, and $\mathrm{W}$ lines. Mature pollen from untransformed (U), null $(\mathrm{N})$, vector $(\mathrm{V})$ and $W U S(\mathrm{~W})$ plants were taken for iodine staining $\left(\mathrm{I}_{2}-\mathrm{KI}\right)$ [51] and the stained images were visualized under Nikon light microscopy [Nikon (C-DSS230) microscope, Tokyo, Japan].

\subsection{RT-PCR Analysis}

The total RNA from U, V, and $\mathrm{W}$ plants were extracted, estimated, and subjected to DNase treatment [52]. Two-step RT-PCR kit (TaKaRa, Kyoto, Japan) was used to synthesize cDNA from DNase treated RNA samples. In the first step, $1 \mu \mathrm{g}$ of RNA was taken along with oligo dT and dNTPs and kept at $65^{\circ} \mathrm{C}$ for $5 \mathrm{~min}$ for the first-strand synthesis. Further RNase inhibitor, RTase, and $5 \mathrm{X}$ RT buffer were added and kept at 
$42^{\circ} \mathrm{C}$ for $30 \mathrm{~min}$ and $95^{\circ} \mathrm{C}$ for 5 min for cDNA synthesis. The cDNA (100 ng) was used for OSACTIN and AtWUS PCR. The actin fragment was amplified using forward primer (5'CTTGCTGGGCGTGATCTCA 3') and reverse primer (5' CAGGGCGATGTAGGAAAGCT 3'). The following condition was used to amplify the actin fragment: $\left[94^{\circ} \mathrm{C}\right.$ for 2 min followed by 35 cycles $\left(94^{\circ} \mathrm{C}\right.$ for $40 \mathrm{sec}, 55^{\circ} \mathrm{C}$ for $40 \mathrm{sec}$, $72^{\circ} \mathrm{C}$ for $1 \mathrm{~min}$ ) and final extension with $72^{\circ} \mathrm{C}$ for $\left.6 \mathrm{~min}\right]$. The WUS cDNA was amplified by the forward primer 5'TATATGGCGGCTAACGA3' and reverse primer 5' GATGATAGAGATGATGGTCTTGG 3'. The following condition was used to amplify the WUS fragment: $\left[94^{\circ} \mathrm{C}\right.$ for 1 min followed by 30 cycles $\left(94^{\circ} \mathrm{C}\right.$ for $40 \mathrm{sec}, 60^{\circ} \mathrm{C}$ for $30 \mathrm{sec}$, $72^{\circ} \mathrm{C}$ for $1 \mathrm{~min}$ ) and final extension with $72^{\circ} \mathrm{C}$ for $\left.5 \mathrm{~min}\right]$.

\section{Results}

\subsection{Generation of $T_{0}$ Transgenic Plants}

Agrobacterium strain LBA4404 (pSB1) harbouring the binary vector, pMG2 (Figure 1), and vector (pCAMBIA1301) were used for rice transformation. After two rounds of selection, a portion of the calli was used for GUS staining (Data not shown). The putative gus positive transgenic calli were transferred to the regeneration medium. Sixteen $W U S$ $(W)$ plants were obtained from two batches of transformation. A portion of the leaf was subjected to GUS staining (Data not shown). The GUS positive putative transformants were transferred to the transgenic greenhouse and maintained till maturity. The PCR performed in the six $\operatorname{WUS}(\mathrm{W})$ and five vector (V) plants confirmed the presence of $1.1 \mathrm{~kb} h p h$ amplicon, and $0.5 \mathrm{~kb}$ gus gene (data not shown).

\subsubsection{Transgene Integration and Copy Number Determination}

Six W plants and five V plants obtained from the first batch of transformation were taken for detailed analyses. All the six putative transgenic plants ( $\mathrm{V}$ and $\mathrm{W}$ ) were digested with HindIII and probed with $h p h$ (LB probe) to determine the junction fragments and the copy number. All the $\mathrm{V}$ and $\mathrm{W}$ plants hybridized fragments $>2.5 \mathrm{~kb}$ except in plants (W3 and V10). Five vector plants (V10, V12, V13, V14, and V16) and 6 WUS transgenic plants (W4, W5, W6, W7, W17, and W18) possessed single-copy T-DNA integration (Figure $2 \mathrm{~A}$ ). The $\mathrm{T}_{0}$ plants, W5 and W6 might be siblings as they possessed similar junction fragments for the LB probe. The $\mathrm{W}$ transgenic plants were subjected to Southern analyses using the WUS gene $(1.6 \mathrm{~kb})$ as a probe. Upon HindIII digestion, a $1.6 \mathrm{~kb}$ internal fragment of the WUS gene is expected to be hybridized for the WUS probe. Among the W plants, 5 plants (W3, W4, W7, W17, and W18) hybridized to WUS fragment (1.6 kb) (Figure 2B).

In the case of W5 and W6, the T-DNA might be truncated at the RB lacking the WUS gene and possess the LB with the $h p h$ gene. This is further evident from the PCR analyses using WUS primers. Both the plants revealed a higher sized amplicon apart from the expected $0.83 \mathrm{~kb}$ (Data not shown). This may be due to the presence of truncated T-DNA at the LB. Henceforth, further analyses were carried out only with the single copy plants (W4, W7, and V13) harbouring complete T-DNA.

(A)
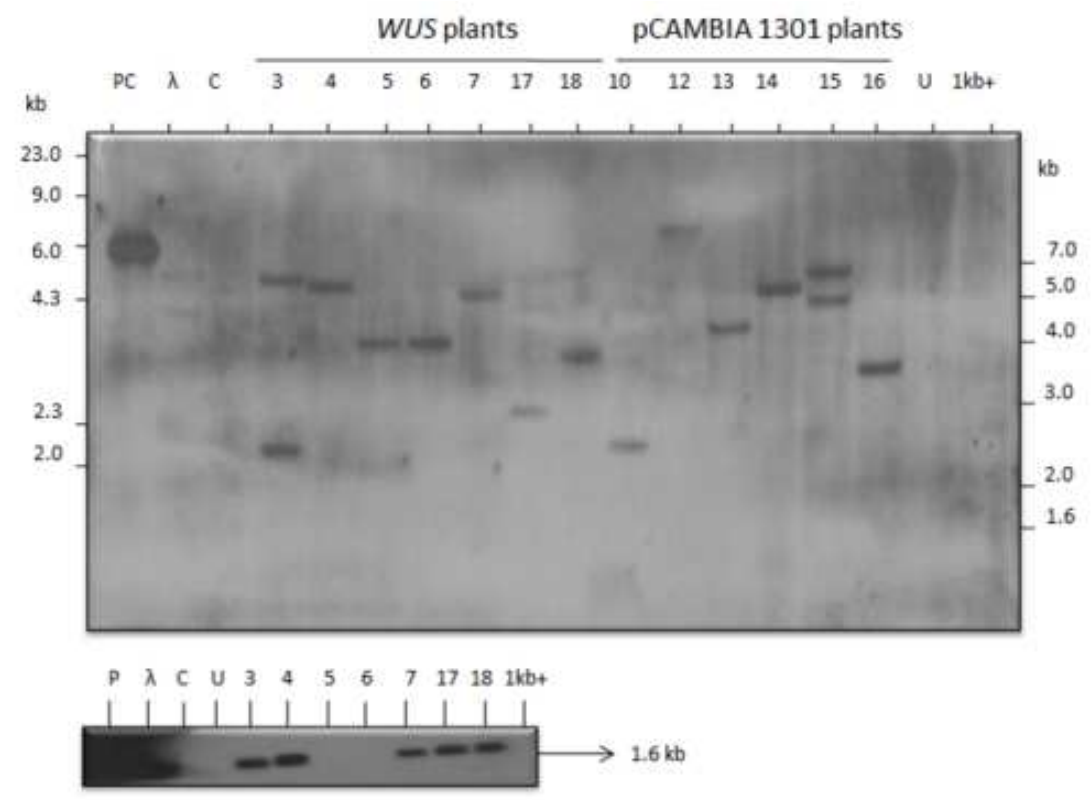

(B)

Figure 2. Southern analysis of $T_{0}$ rice plants transformed with A. tumefaciens LBA4404 (pSBI, pMG2) and LBA4404 (pSB1, pCAMBIA1301) using (A) hph as the probe and $(B)$ WUS as the probe. Numbers on the top refers to $T_{0}$ lines. Five $\mu \mathrm{g}$ of plant DNA was digested with HindIII and electrophoresed. $C-D N A$ from untransformed control plant digested with HindIII, U-Undigested DNA from To plant, $1 \mathrm{~kb}+-1 \mathrm{~kb}+$ ladder, PC-Positive control, P-Probe.

\subsubsection{Morphology of $T_{0}$ Plants}

The control (U) plants and putative transgenic lines, $\mathrm{V}$ and $\mathrm{W}$ were acclimatized in the transgenic greenhouse. The $\mathrm{U}$ and $\mathrm{V}$ plants started flowering after 60-70 days while the $\mathrm{W}$ transgenic plants were still in the vegetative stage with faded leaf color (Figure 3A). The $\mathrm{W}$ transgenic plants started flowering only after 90-120 days. They also exhibited a 
panicle enclosed phenotype. As the $T_{0}$ plants were hemizygous, few of the panicles were found to be closed (Figure 3B). The heading date was found to be increased in
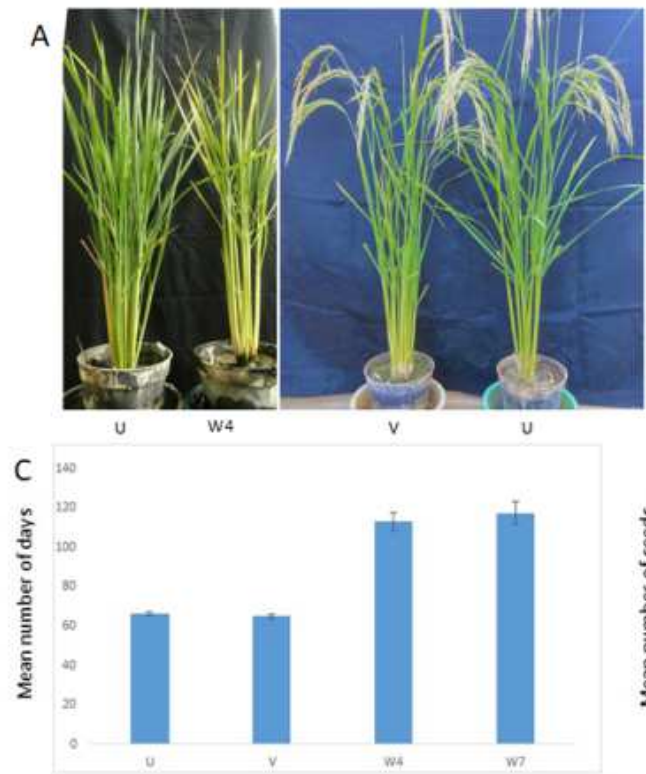

W plants compared to $\mathrm{U}$ and $\mathrm{V}$ plants (Figure 3C). The total number of seeds obtained from the $\mathrm{T}_{0}$ transgenic plants of $\mathrm{W}$ was less (Figure 3C) compared to $\mathrm{U}$ and $\mathrm{V}$ plants.

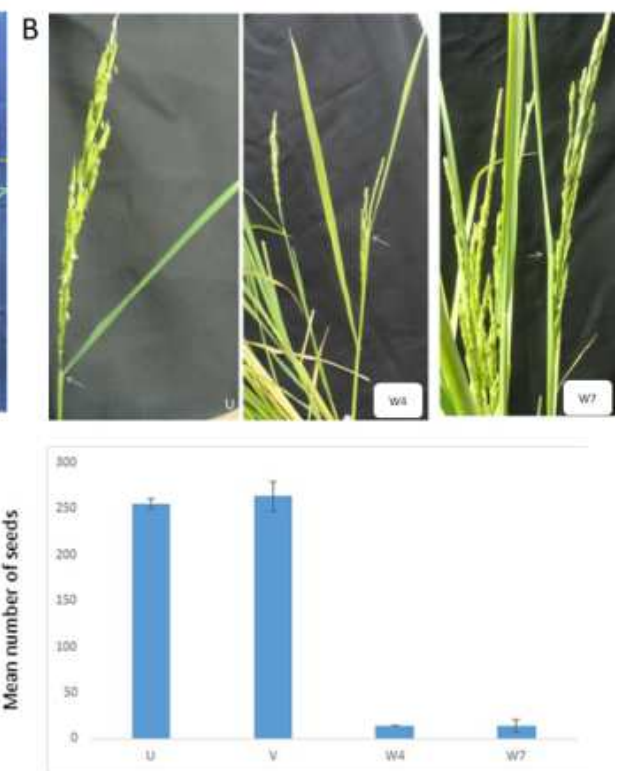

Figure 3. A. Morphology of $T_{0}$ WUS line 4 (W4) compared to untransformed (U) and vector (V), B. Panicle enclosure type in $U$ and two $W$ lines (W4 \& W7) (arrow indicates the collar), $C$. Analyses of heading date and seed formation in $U, V$ and two $W$ lines (W4 \& W7).

\subsubsection{Inheritance of Transgene}

The seeds from two $\mathrm{T}_{0}$ plants, W4 and W7 along with V13 were scored for hygromycin resistance and the data were statistically validated by the $\chi^{2}$ test. All the $\mathrm{T}_{1}$ lines (V13, $\mathrm{W} 4$, and W7) revealed a 3:1 segregation ratio thus confirming the inheritance of single-copy T-DNA at a single locus (Table 1). Ten $\mathrm{T}_{1}$ transgenic plants from $\mathrm{W} 4$ and eight transgenic plants from $\mathrm{W} 7$ were taken for further homozygosity analysis. Of these, only 3 plants (W4-1, W410, and W7-2) had more than 20 seeds (Table 2). For further validation, $12 \mathrm{~T}_{1}$ plants from line W4-10 along with 3 null $(\mathrm{N})$, and $\mathrm{U}$ plants were analyzed (data not shown). There was no difference between $\mathrm{U}, \mathrm{V}, \mathrm{N}$, and $\mathrm{W}$ plants during the vegetative stage until 60 days. After 60 days the stem was hollow in $\mathrm{U}$ and $\mathrm{V}$ plants (data not shown). On the other, the stem was still thick (vegetative) in the W plants (Figure 4).

Table 1. Segregation analysis of $T_{0}$ lines.

\begin{tabular}{llllll}
\hline $\begin{array}{l}\text { To plant } \\
\text { line no. }\end{array}$ & $\begin{array}{l}\text { Total no. of } \\
\text { seeds }\end{array}$ & GUS $^{+ \text {ve }}$ & GUS $^{\text {-ve }}$ & $\chi^{2}$ (3:1) & P-value \\
\hline W4 & 20 & 16 & 4 & 0.27 & $>0.60$ \\
W7 & 40 & 34 & 6 & 2.13 & $>0.14$ \\
V13 & 40 & 31 & 9 & 0.13 & $>0.72$ \\
\hline
\end{tabular}

Table 2. Segregation analysis of $T_{1}$ plant seeds harbouring WUS gene.

\begin{tabular}{llllll}
\hline $\begin{array}{l}\text { Ti } \boldsymbol{W U S} \\
\text { plant no. }\end{array}$ & $\begin{array}{l}\text { Total no. } \\
\text { of seeds }\end{array}$ & GUS $^{\text {+ve }}$ & GUS $^{\text {-ve }}$ & $\begin{array}{l}\boldsymbol{\chi} \mathbf{2} \\
\mathbf{( 3 : 1 )}\end{array}$ & P-value \\
\hline W4-1 & 23 & 18 & 5 & 0.13 & $>0.72$ \\
W4-10 & 33 & 24 & 9 & 0.09 & $>0.76$ \\
W7-2 & 20 & 12 & 8 & 2.40 & $>0.12$ \\
W7-9 & 16 & 11 & 5 & 0.02 & $>0.89$ \\
\hline
\end{tabular}

The vegetative stage of $\mathrm{W}$ plants was found to be increased than the $\mathrm{U}$, and $\mathrm{V}$ plants (Data not shown), and there is the inheritance of the panicle enclosed phenotype in W lines (Data not shown). Such a panicle enclosed phenotype might have been due to the defective internode elongation (Data not shown). The loss of panicle exertion affected the panicle morphology (Figure 5A) and it subsequently affected the grain numbers also to a greater extent (Figure 3C). Seed setting (Figure 6B) was highly affected in $\mathrm{W}$ plants due to the presence of an unopen flower (Figure 6A) and defective pollen. The WUS expressed $\mathrm{T}_{1}$ plants, W4-6, and W4-9 were screened for anther color and pollen viability (Figure 6D). The anther color and its morphology under a light microscope revealed pale yellow compared to yellow color in control (Figure 6B). The difference in the anther color intensity was also confirmed using ImageJ software (Figure 5B).

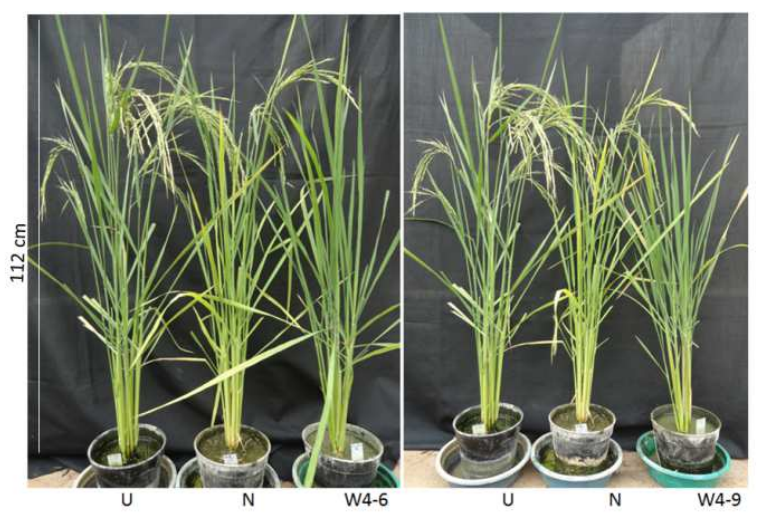

Figure 4. Morphology of untransformed (U), vector (V), and WUS (W) lines. 
A

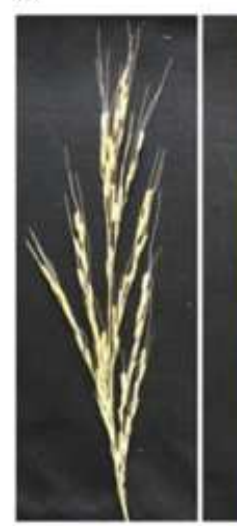

u

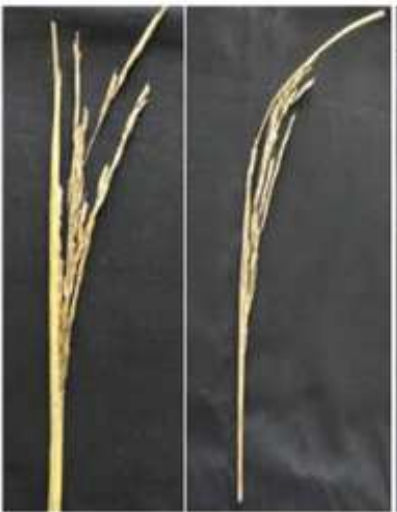

W4.9
B
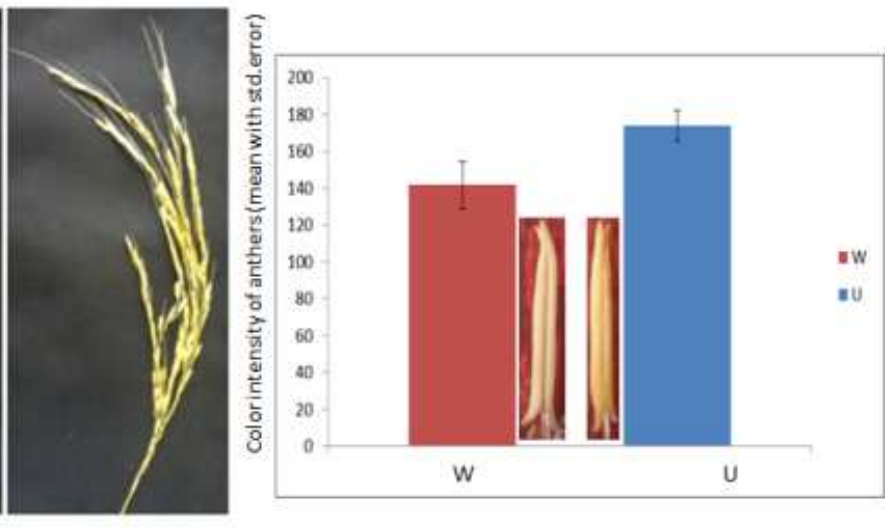

Figure 5. A. Disorganized panicle structure in T1 WUS lines (W4-6 and W4-9), B. Measurement of colour intensity of anthers using Image J software in W and U plants.
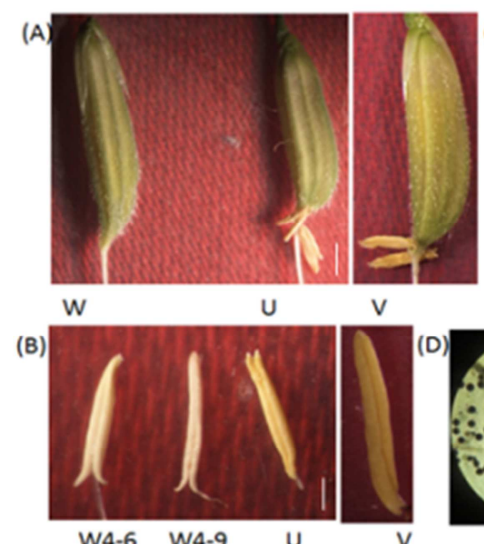

W4-6 W4-9

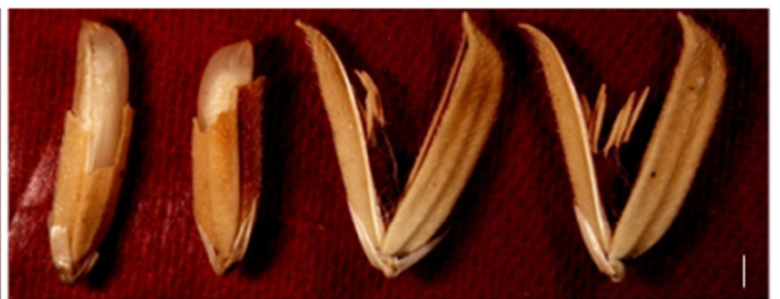

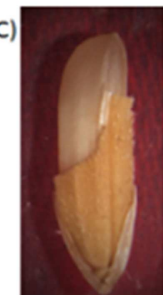

$\mathrm{V}$

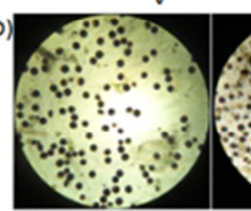

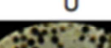

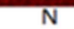

W4-6

W4-9

$\mathrm{V}$

$\mathrm{N}$

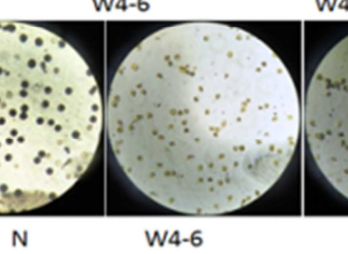

W4-6

Figure 6. Phenotypic characteristics of (A) individual spikelet (unopen), (B) pale yellow color anther, (C) Seed setting and (D) pollen viability of untransformed (U), null (N), vector (V) and WUS (W) Lines (W4-6, W4-9) (Bars - A - $10 \mathrm{~mm}, \mathrm{~B}-2 \mathrm{~mm}, \mathrm{C}-100 \mathrm{~mm}, \mathrm{D}-10 \mathrm{X}$ magnification).

Among the $\mathrm{T}_{1}$ plants of W4, only three plants (W4-6, W47, and W4-9) lost pollen viability and there were no seeds. These 3 plants were completely abnormal in phenotype and those might be homozygous plants due to the expression of WUS at both locus. The homozygosity was further confirmed by the RT-PCR by analyzing two homozygous plants along with the hemizygous and U plants (Figure 7C). The crosssection of 20 days old leaf sheath revealed mature vascular bundles that might have been arisen earlier than the $U$ plants (data not shown). Besides, the leaves of $\mathrm{W}$ plants possess one smaller vein which was absent in the $\mathrm{U}$ and $\mathrm{V}$ plants (Data not shown). The RT-PCR analysis revealed that the expression of WUS in the leaves (Figure 7A).

\subsection{Embryogenic Calli Formation and Regeneration}

The WUS expression in homozygous plants affected the panicle phenotype and pollination. The RT-PCR result confirmed the WUS gene expression in young panicles of W4-6 compared to the U and V plants (Figure 7B). Hence, there was no seed formation in homozygous plants. Due to the failure in generating homozygous plants, the hemizygous plants were subjected to callus induction and regeneration.
(A)
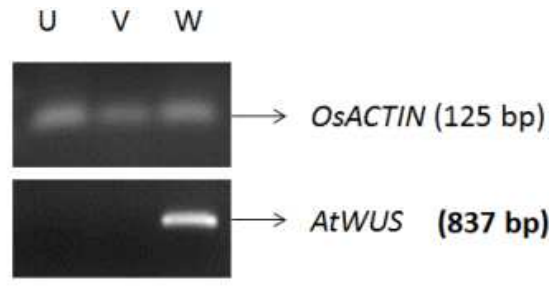

(B)

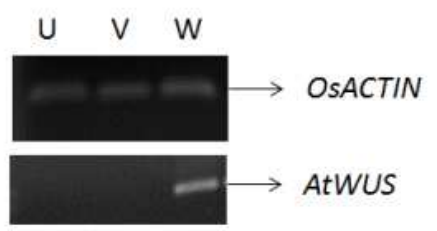

(c)

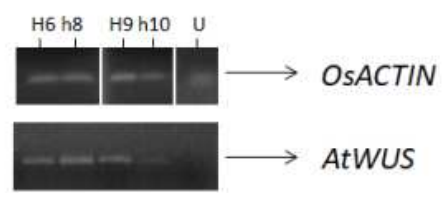

Figure 7. RT-PCR expression of the leaf (A) and panicle (B) (less than 1.5 $\mathrm{cm})$ from $U, V$, and $W$ plants $(C) R T-P C R$ expression in homozygous $(H)$, hemizygous (h) and $U$ plants. 
The seeds from two hemizygous lines (W4-10-5 and W410-11) along with $U$ and $V$ lines were evaluated for the embryogenic calli formation and regeneration. The $T_{1}$ hemizygous seeds were surface sterilized, kept in dark for 21 days, and observed at regular intervals for embryogenic structures. The number of seeds from $\mathrm{W}$ lines in generating embryogenic calli were not statistically different from the control seeds (data not shown). The only difference was that
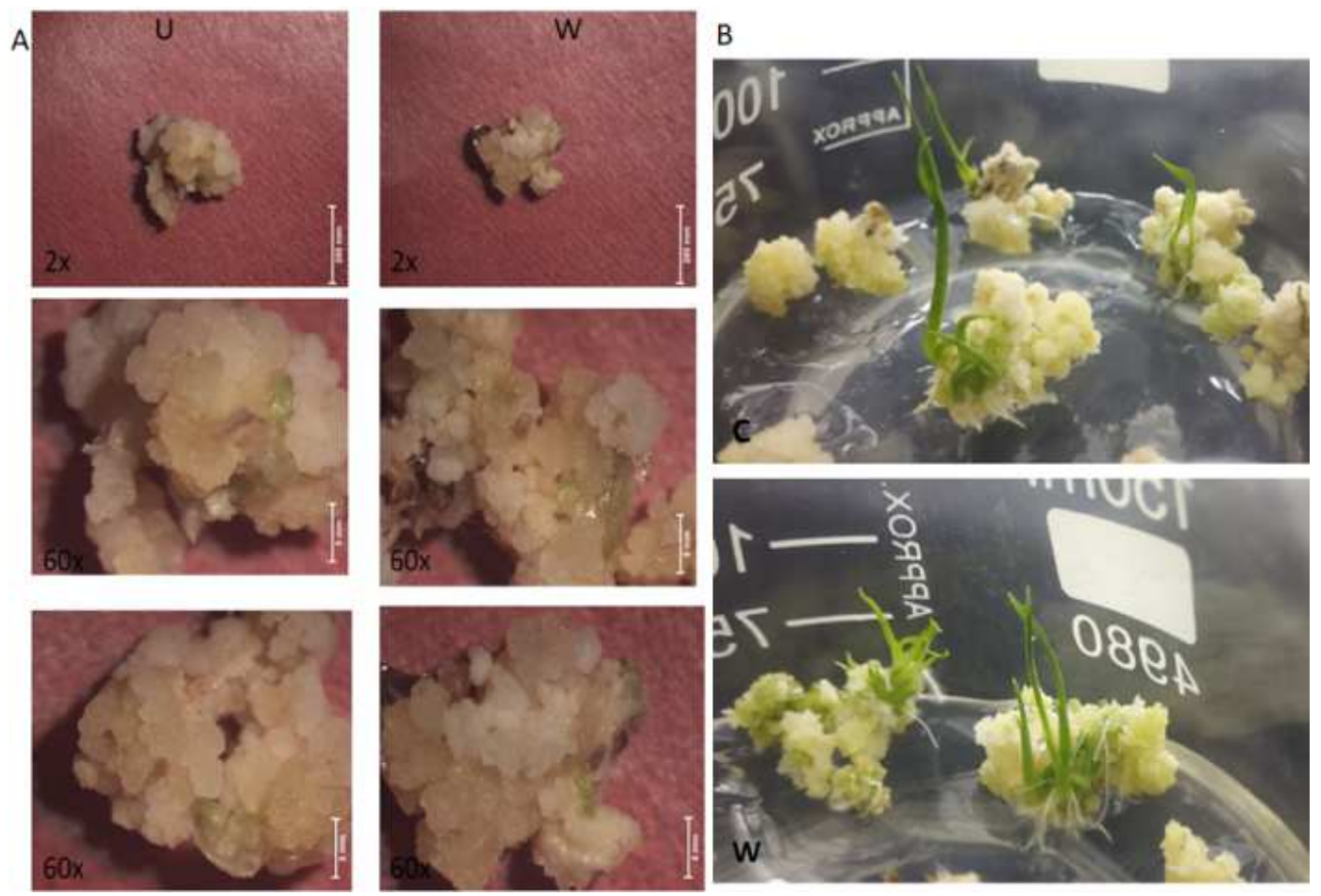

Figure 8. Embryogenic calli regeneration under the microscope (A) and multiple shoot formation in $W$ plants compared to $U$ plants.

\section{Discussion}

One of the major hurdles in transgenic technology includes the regeneration potential is difficult in recalcitrant crops. Efficient plant regeneration can be achieved via somatic embryogenesis and organogenesis. Nowadays, basic research on the above well-defined areas is expanding. The role of the DGs and their network involved in morphogenesis are explored in detail. But the detailed characterization of such DGs includes either ectopic overexpression or downregulation in plants. The overexpression of DGs had resulted in deleterious pleiotropic effects, it's of utmost importance to understand the negative impact of overexpression of DGs [53]. One such DG is AtWUS, a master regulator in plant growth signaling. The overexpression of AtWUS led to embryogenic calli formation, vegetative to embryonic transition, delay in heading date and flowering, and panicle enclosure phenotype.

\subsection{AtWUS Gene Promotes Embryogenesis and Regeneration}

Somatic embryogenesis is an important tool for crop improvement and depends on calli induction and the calli from $\mathrm{W}$ lines were whitish with more embryo-like structures compared to $\mathrm{U}$ plants. The calli from $\mathrm{W}$ lines turned greenish (Figure 8A) earlier than the $\mathrm{U}$ and $\mathrm{V}$ lines. Further, the transition to greenish like structures from the embryogenic calli was found to be higher in $\mathrm{W}$ lines compared to $\mathrm{U}$ and $\mathrm{V}$ plants. The shoots obtained from the $\mathrm{W}$ callus were numerous compared to the $\mathrm{U}$ callus (Figure $8 \mathrm{~B}$ ). regeneration. The embryogenic calli and the subsequent regeneration depends upon the genotype, preculturing, hormonal conditions, and methods of transformation [54]. Three types of calli were developed in callus induction, embryogenic, non-embryogenic, and rhizogenic. Only embryogenic or friable embryogenic calli has the potential to regenerate through somatic embryogenesis [55]. Such embryogenic calli formation requires plant growth regulators, carbon sources, and basal media. Apart from the external sources, several genes need to be activated at the seed level to promote somatic embryogenesis [56-58] as evident in Arabidopsis. The WUS gene expression increased the embryogenic calli formation in G. hirsutum [36], embryolike structures in Arabidopsis [17], and ectopic changes in the calli of $C$. chinense [31]. In our results, the calli obtained from $\mathrm{T}_{1}$ seeds (hemizygous) of $\mathrm{W}$ plants tend to be embryogenic compared to $\mathrm{U}$ and $\mathrm{V}$ plants (data not shown). Ectopic organogenesis was also increased in G. hirsutum [35]. The regeneration ability of the calli was also increased by more embryogenic calli formation [40]. In our study, the regeneration of the embryogenic calli was enhanced compared to $\mathrm{U}$ and $\mathrm{V}$ plants. Also, the calli turned greenish and generated multiple shoots compared to $\mathrm{U}$ and V plants. Our study also confirmed the ectopic organogenesis (Figure 
$8 \mathrm{~B})$ in rice, as evident in other plants upon WUS overexpression.

\subsection{Overexpression of AtWUS Increased the Vegetative Development}

The WUS overexpression in rice under the actin promoter resulted in the small and twisted leaf [30]. Apart from WUS, WOX genes also play a role in somatic embryogenesis, regeneration from leaf segments, early and lateral leaf development. Among the WOX genes, overexpression of the WOX3 gene induced the expression of $K N O X$ genes at embryo development and inflorescence meristem. The WOX3 overexpression altered the leaf morphology while WOX4 failed to develop vegetative meristem revealed by RNAi studies [27]. WOX3 is highly conserved in gymnosperms, basal angiosperms, eudicots, and monocots. In rice, WOX3 plays a role in leaf development [59]. WOX4 is also highly conserved in Arabidopsis and rice and strongly expressed in leaf primordia while the lateral organs showed reduced expression [27]. Previously in tobacco, the WUS expression altered the leaf structure, conjoined leaves, and vein pattern [60]. In our study, overexpression of the AtWUS gene increased the leaf primordia in the leaf sheath and increased the matured vascular bundle in leaf. Interestingly, one smaller vein was additionally evident in the leaves of $\mathrm{W}$ plants while it was absent in $\mathrm{U}$ and $\mathrm{V}$ plants. From our studies, the role of the WUS gene plays a role in vein formation apart from leaf development (Data not shown). Apart from leaf, the tiller was cross-sectioned at 60 days to check any alteration in the vegetative development. The results showed the $\mathrm{W}$ plants were not yet bolted compared to U and V plants (Figure 4).

\subsection{AtWUS Overexpression Leads to Delayed Heading Date and Flowering}

Heading date was genotype-dependent and it is controlled by basic vegetative growth and photoperiod sensitivity in japonica rice variety [61]. Many genes were involved in regulating the heading date in rice by complex interactions starting from the vegetative stage to the flowering stage. The gene OsId1 (Inderterminate1) in rice is essential to activate either $H d 1$ (Heading date 1) or the Ehdl (Early HD1), which will activate the expression of $H d 3 a$ and $R F T$ genes [62]. The ehdl mutation affected the expression of $H d 3 a$ and also the floral transition. Hence it plays a significant role in floral meristem formation and its development [63]. The reduction in internode is associated with the reduced synthesis of IAA and GA resulted in panicle enclosure. The enclosed panicle affects the grain number due to the loss of pollen fertility. The delay in heading date affected the yield rate in different cultivars of rice in China [64]. In our results, both the $\mathrm{T}_{0}$ plants (Figure $3 \mathrm{~A}$ ) and $\mathrm{T}_{1}$ plants (Figure 4), the heading date (Figure 3C) was delayed. As a result, the numbers of seeds were decreased in $\mathrm{W}$ plants compared to $\mathrm{U}$ and $\mathrm{V}$ lines. Also, WUS expressed lines possessed a tightly packed stem rather than the normal one (data not shown). Overall our results revealed that the expression of the WUS gene (Figure 7B) is associated with the delay in heading date, increased vegetative growth, and the severe reduction in internode elongation length (Data not shown).

\subsection{Panicle Enclosure}

Panicle enclosure refers to the enclosure of the panicles either partly or fully with the flag leaf sheath. This phenotype is commonly found in almost all CMS (cytoplasmic male sterile) lines. This phenotype seriously affected the hybrid rice production as the normal pollination is affected in rice. The level of the gibberellic acid $A_{1}\left(G_{1}\right)$ played a major role in internode elongation in rice [65]. The GA1 deficiency in the uppermost internode (UI) leads to the decreased synthesis of the indole acetic acid (IAA) resulted in a panicle enclosure phenotype [66]. Panicle enclosure was also studied in mutants of rice shortened uppermost internode 1 (suil-1 and suil-2) plants which showed partly sheathed and fully sheathed panicle respectively. Gibberellin treatment also not increased the SUI due to the decreased longitudinal cell length in rice [67]. Panicle enclosure affected the panicle morphology. Previously the allele, PANICLE PHYTOMER 1 $(P P 1)$ upon mutation affected the panicle structure with increased primary rachis in two different rice cultivars in Japan [68]. In our study, the number of altered branches emerging out of the sheath was noted in WUS transgenic plants (W4-6 and W4-9) not in U and V plants (Figure 5A). Also, the WUS gene expression (Figure 7) affected the internode length that leads to the panicle enclosure phenotype (data not shown). Hence the further developmental stages were affected.

Panicle enclosed phenotype affected the pollination severely [67]. Our results also confirmed that severity in the phenotype affected the pollination and resulted in unopen flower morphology (Figure 6A). The anthers were not able to fertilize due to the pale yellow color of the anther (Figure 6B). Pale yellow color anther lacks mature pollen [67]. The pale yellow color anther was measured and confirmed by ImageJ software (Figure 5B). The defect in the pollination led to a reduction in the seed formation in $T_{0}$ plants. In our study, the $T_{1}$ plant seeds were screened to identify the homozygous lines. No homozygous plant was identified during the inheritance of WUS until $\mathrm{T}_{2}$ generation. The expression of the WUS gene was confirmed in the hemizygous and homozygous plants (Figure 7C). The hemizygous plants also showed a delay in the heading. The $\mathrm{N}$ plants were checked whether the integration of T-DNA or the expression of WUS affected the plant development. However, the $\mathrm{N}$ plants were normal like the $\mathrm{U}$ plants. Among the 12 WUS plants, 3 plants did not set seeds due to the panicle enclosed phenotype and defective flowers. The $T_{1}$ hemizygous plants only produced seeds and were less in number compared to $\mathrm{U}, \mathrm{V}$, and $\mathrm{N}$ plants. Thus, we conclude that those 3 plants with defective seeds might be homozygous due to the expression of WUS at both the loci. The higher level of WUS expression affected the homozygous rice plants at all vegetative (Figure 7A), inflorescence (Figure 7B) and flower development stages, and lacked the seed formation. 


\section{Conclusion}

The efficient transformation relies on embryogenic calli formation and regeneration through somatic embryogenesis. Many morphogenic genes were involved in somatic embryogenesis. Identification of such morphogenic genes would be a useful tool in improving transgene technology. Many reports revealed that timely expression of DGs would be useful in improving transformation in recalcitrant crops. Our study provides evidence that the AtWUS gene under constitutive promoter in rice tends to turn the calli embryogenic and enhanced the transition towards regeneration. However, the ectopic expression of the AtWUS gene in rice led to the pleiotropic effects such as tightly packed stem, panicle enclosure phenotype, delay in heading date, pale yellow color anther, defective in seed setting and pollen viability. Interestingly, the overexpression did not affect the crown root formation (Data not shown). The AtWUS overexpression increased the regeneration at the embryogenic level in cotton, Capsicum, and Arabidopsis. Our results also revealed that the ectopic expression led to increased somatic embryogenesis and attained early regenerative phase irrespective of all the pleiotropic effects.

\section{Acknowledgements}

The authors are thankful to the University Grants Commission, New Delhi, India for the major research project and UGC-BSR fellowship for TV. We thank Mr. A. Muthuganeshan in the construction of binary vectors and mobilization into Agrobacterium. We thank Professor NamHai Chua, Rockefeller University, USA for the vector pER10 harbouring AtWUS gene. We thank Professor K. Veluthambi, Department of Plant Biotechnology, School of Biotechnology, Madurai Kamaraj University, Madurai-21, Tamil Nadu, India for extending his facilities to carry out the above research work.

\section{References}

[1] Nagle M, Dejardin A, Pilate G, Strauss SH (2018) Opportunities for innovation in genetic transformation of forest trees, Front. Plant Sci 9: 1443. DOI: 10.3389/fpls.2018.01443.

[2] Ikeuchi M, Ogawa Y, Iwase A, Sugimoto K (2016) Plant regeneration: cellular origins and molecular mechanisms. Development 143: 1442-1451.

[3] Lowe K, Wu E, Wang N, et al. (2016) Morphogenic regulators Baby boom and Wuschel improve monocot transformation. Plant Cell 28 (9): 1998-2015. DOI: 10.1105/tpc.16.00124.

[4] Altpeter F (2016) Advancing crop transformation in the era of genome editing. Plant Cell 28: 1510-1520.

[5] Gordon-Kamm B, Sardesai N, Arling M, Lowe K, Hoerster G, Betts S, Jones T (2019) Using morphogenic genes to improve recovery and regeneration of transgenic plants. Plants 8: 38 .
[6] Thomas $\mathrm{T}$ (1993) Gene expression during plant embryogenesis and germination: An overview. Plant Cell 5: 1401-1410.

[7] Schmidt EDL, Guzzo F, Toonen MAJ, de Vries SC (1997) A leucine-rich repeat-containing receptor-like kinase marks somatic plant cells competent to form embryos. Development 124: 2049-2062.

[8] Bratzel F, López-Torrejón G, Koch M, Del Pozo JC, Calonje M (2010) Keeping cell identity in Arabidopsis requires PRC1 RING-finger homologs that catalyze H2A monoubiquitination. Curr Biol 26: 1853-9.

[9] Chen D, Molitor A, Liu C, Shen WH (2010) The Arabidopsis PRC1-like ring-finger proteins are necessary for repression of embryonic traits during vegetative growth. Cell Res 20 (12): 1332-44.

[10] Yang C, Bratzel F, Hohmann N, Koch M, Turck F, Calonje M (2013) VAL- and AtBMI1-mediated H2Aub initiate the switch from embryonic to post germinative growth in Arabidopsis. Curr Biol 23 (14): 1324-9.

[11] Xu L, Huang H (2014). Genetic and epigenetic controls of plant regeneration. Current topics in developmental biology 108: 1-33. 10.1016/B978-0-12-391498-9.00009-7.

[12] Ikeda M, Ohme-Takagi M (2014) TCPs, WUSs, and WINDs: families of transcription factors that regulate shoot meristem formation, stem cell maintenance, and somatic cell differentiation. Front Plant Science 5: 427.

[13] Heyman J, Canher B, Bisht A, Christiaens F, De Veylder L (2018) Emerging role of the plant ERF transcription factors in coordinating wound defense responses and repair. J Cell Sci 131: jcs208215. https://doi.org/10.1242/jcs.208215

[14] Ikeuchi M, Shibata M, Rymen B, Iwase A, Bågman A-M, et al. (2018) A gene regulatory network for cellular reprogramming in plant regeneration. Plant Cell Physiol 59 (4): $770-82$.

[15] Gehring WJ, Qian YQ, Billeter M (1994) Homeodomain-DNA recognition. Cell 78 (2): 211-223. DOI: 10.1016/00928674(94)90292-5.

[16] Van der Graff E., Laux T., Rensing SA (2009) The WUS homeobox-containing (WOX) protein family. Genome Biology 10: 248.

[17] Zuo J, Niu QW, Frugis G, Chua NH (2002) The WUSCHEL gene promotes vegetative-to-embryonic transition in Arabidopsis. The Plant Journal 30: 349-359.

[18] Lenhard M, Jurgens G, Laux T (2002) The WUSCHEL and SHOOTMERISTEMLESS genes fulfill complementary roles in Arabidopsis shoot meristem regulation. Development 129: 3195-3206.

[19] Laux T, Mayer KFX, Berger J, Jurgens G (1996) The WUSCHEL gene is required for shoot and floral meristem integrity in Arabidopsis. Development 122: 87-96.

[20] Mayer KFX., Schoof H, Haecker A, Lenhard M, Jurgens G, Laux T (1998) Role of WUSCHEL in regulating stem cell fate in the Arabidopsis shoot meristem. Cell 95: 805-815.

[21] Lohmann JU, Hong RL, Hobe M, et al. (2001) A molecular link between stem cell regulation and floral patterning in Arabidopsis. Cell 105 (6): 793-803. doi: 10.1016/s00928674(01)00384-1. 
[22] Nardmann J, Werr W (2006) The shoot stem cell niche in angiosperms: expression patterns of WUS orthologues in rice and maize imply major modifications in the course of monoand dicot evolution. Mol Biol Evol 23 (12): 2492-504.

[23] Lu Z, Shao G, Xiong J, Jiao Y, Wang J, Liu G, Meng X, Liang Y, Xiong G, Wang Y, Li J (2015) MONOCULM 3, an ortholog of WUSCHEL in rice, is required for tiller bud formation. Journal of Genetics and Genomics 42: 71-78.

[24] Tanaka W, Ohmori Y, Ushijima T, Matsusaka H, Matsushita T, Kumamaru T, Kawano S, Hiranoa HY (2015) Axillary meristem formation in rice requires the WUSCHEL ortholog TILLERS ABSENT1. Plant Cell 27: 1173-1184.

[25] Tanaka W, Hirano HY (2019) Antagonistic action of TILLERS ABSENT1 and FLORAL ORGAN NUMBER2 regulates stem cell maintenance during axillary meristem development in rice. New Phytologist DOI: 10.1111/nph.16163.

[26] Suzuki C, Tanaka W, Tsuji H, Hirano HY (2019) TILLERS ABSENT1, the WUSCHEL ortholog, is not involved in stem cell maintenance in the shoot apical meristem in rice. Plant Signal Behav 14 (9): $1640565 . \quad$ DOI: 10.1080/15592324.2019.1640565.

[27] Ohmori Y, Tanaka W, Kojima M, Sakakibara H, Hirano HY (2013) WUSCHEL-RELATED HOMEOBOX4 is involved in meristem maintenance and is negatively regulated by the $C L E$ gene FCP1 in rice. Plant Cell 25: 229-241.

[28] Weiss J, Rodriguez RA, Toksoz T, Cortines ME (2016) Meristem maintenance, auxin, jasmonic, and abscisic acid pathways as a mechanism for phenotypic plasticity in Antirrhinum majus. Scientific Reports 6: 19807.

[29] Ferrario S, Shchennikova AV, Franken J, Immink RGH, Angenent GC (2006) Control of floral meristem determinacy in Petunia by MADS-Box transcription factors. Plant Physiology 140: 890-898.

[30] Kamiya N, Nagasaki H, Morikami A, Sato Y, Matsuoka M (2003) Isolation and characterization of a rice WUSCHELtype homeobox gene that is specifically expressed in the central cells of a quiescent center in the root apical meristem. Plant J 35 (4): 429-441. DOI: 10.1046/j.1365313x.2003.01816.x.

[31] Ramos LYS, Estrada TG, Dzib SN, Rodriguez LCZ, Castano E (2008) Overexpression of WUSCHEL in C. chinense causes ectopic morphogenesis. Plant Cell Tissue Organ Culture 96: 279-287.

[32] Klimaszewska K, Overton C, Stewart D, Rutledge RG (2011) Initiation of somatic embryos and regeneration of plants from primordial shoots of 10-year-old somatic white spruce and expression profiles of 11 genes followed during the tissue culture process. Planta 233 (3): 635-47.

[33] Herrera AA, Gonzalez KA, Moo CR, Figueroa FRQ, Vargas VML, Zapata LCR, DHondt CB, Solis VMS, Castano E (2008) Expression of WUSCHEL in Coffea canephora causes ectopic morphogenesis and increases somatic embryogenesis. Plant Cell Tissue Organ Culture 94: 171. https://doi.org/10.1007/s11240-008-9401-1

[34] Hu L, Yang X, Yuan D, Zeng F, Zhang X (2011) GhHmgB3 deficiency deregulates proliferation and differentiation of cells during somatic embryogenesis in cotton. Plant Biotechnol J 9 (9): $1038-48$.

[35] Coussa OB, Obellianne M, Linderme D, Montes E, Grondard
AM, Vilaine F, Pannetier C (2013) Wuschel overexpression promotes somatic embryogenesis and induces organogenesis in cotton (Gossypium hirsutum L.) tissues cultured in vitro. Plant cell reports 32: 675-686.

[36] Zheng W, Zhang X, Yang Z, Wu J, Li F, Duan L, Liu C, Lu L, Zhang C, Li F (2014) AtWuschel promotes the formation of the embryogenic callus in Gossypium hirsutum. PLOS ONE 9: e87502.

[37] Gaj MD, Zhang S, Harada JJ Lemaux PG (2005) Leafy cotyledon genes are essential for the induction of somatic embryogenesis of Arabidopsis. Planta 222 (6): 977-88.

[38] Fambrini M, Durante C, Cionini G, Geri C, Giorgetti L, Michelotti V, Salvini M, Pugliesi C (2006) Characterization of LEAFY COTYLEDON1-LIKE gene in Helianthus annuus and its relationship with zygotic and somatic embryogenesis. Dev Genes Evol 216 (5): 253-64.

[39] Hao Q, Zhang L, Yang Y, Shan Z, Zhou XA (2019) GenomeWide Analysis of the WOX Gene Family and Function Exploration of GmWOX18 in Soybean. Plants (Basel). 8 (7): 215, Published 2019 Jul 11. DOI: 10.3390/plants8070215.

[40] Lowe K, La Rota M, Hoerster G, et al. (2018) Rapid genotype "independent" Zea mays L. (maize) transformation via direct somatic embryogenesis. In Vitro Cell Dev Biol Plant. 54 (3): 240-252. DOI: 10.1007/s11627-018-9905-2.

[41] Jones T, Lowe K, Hoerster G, Anand A, Wu E, Wang N, Arling M, Lenderts B, Gordon-Kamm W (2018) Maize transformation using the morphogenic genes Baby Boom and Wuschel2, in Sandeep Kumar et al., (eds) Transgenic Plants: Methods and Protocols, Methods in Molecular Biology, vol. 1864. https://doi.org/10.1007/978-1-4939-8778-8_6

[42] Mookkan M, Nelson-Vasilchik K, Hague J, Zhang ZJ, Kausch AP (2017) Selectable marker independent transformation of recalcitrant maize inbred B73 and sorghum P898012 mediated by morphogenic regulators $B A B Y B O O M$ and WUSCHEL2. Plant Cell Rep 36 (9): 1477-1491. DOI: 10.1007/s00299-0172169-1.

[43] Kyo M, Maida K, Nishioka Y, Matsui K (2018) Coexpression of WUSCHEL related homeobox (WOX) 2 with WOX8 or WOX9 promotes regeneration from leaf segments and free cells in Nicotiana tabacum L. Plant Biotechnology 35: 23-30.

[44] Vijayachandra K, Palanichelvam K, Veluthambi K (1995) Rice scutellum induces Agrobacterium tumefaciens vir genes and T-strand generation. Plant Molecular Biology 29: 125133.

[45] Sridevi G, Sabapathi N, Meena P, Nandakumar R, Samiyappan R, Muthukrishnan S, Veluthambi K (2003) Transgenic indica rice variety Pusa Basmati 1 constitutively expressing a rice chitinase gene exhibits enhanced resistance to Rhizoctonia solani. Journal of Plant Biochemistry and Biotechnology 12: 93-101.

[46] Hiei Y, Ohta, S, Komari T, Kumashiro T (1994) Efficient transformation of rice (Oryza sativa L.) mediated by Agrobacterium and sequence analysis of the boundaries of the T-DNA. Plant Journal 6: 271-282.

[47] Rogers SO, Bendich AJ (1988) Extraction of DNA from plant tissues. In: Gelvin S. B., Schilperoort R. A., Verma D. P. S. (eds) Plant Molecular Biology Manual. Kluwer Academic Publishers, Dordrecht, USA: 1-10. 
[48] Brunck CF, Jones KC, James TW (1979) Assay for nanogram quantities of DNA in cellular homogenates. Analytical Biochemistry 92: 497-500.

[49] Southern EM (1975) Detection of specific sequences among DNA fragments separated by gel electrophoresis. Journal of Molecular Biology 98: 503-517.

[50] Murashige T, Skoog F (1962) A revised medium for rapid growth and bioassays with tobacco tissue cultures. Physiologia Plantarum 15: 473-497.

[51] Pedersen JF, Bean SR, Funell DL, Graybosch RA (2004) "Rapid Iodine Staining Techniques for Identifying the Waxy Phenotype in Sorghum Grain and Waxy Genotype in Sorghum Pollen." Crop Science 44 (3): 764-767.

[52] Umesh PP, Ansari MA, Sridevi G (2017). An efficient method for high-quality RNA extraction from Moringa oleifera. Journal of Plant Sciences 5 (2): 68-74.

[53] Shin H, Braendle C, Monahan KB, Kaplan REW, Zand TP, Mote FS, et al. (2019) Developmental fidelity is imposed by genetically separable RalGEF activities that mediate opposing $\begin{array}{lllll}\text { signals. PLoS Genet } 15 & \text { (5): } 1008056 .\end{array}$ https://doi.org/10.1371/journal.pgen.1008056.

[54] Liu J, Zheng Q, Ma Q, Gadidasu KK, Zhang P (2011) Cassava genetic transformation and its application in breeding. J Integr Plant Biol 53: 552-569.

[55] Ma QX, Zhou WZ, Zhang P (2015) Transition from somatic embryo to friable embryogenic callus in cassava: dynamic changes in cellular structure, physiological status, and gene expression profiles. Front Plant Sc, 6: 1-14.

[56] Mordhorst AP, Voerman KJ, Hartog MV, Meijer EA, van Went J, Koornneef M, de Vries SC (1998) Somatic embryogenesis in Arabidopsis thaliana is facilitated by mutations in genes repressing meristematic cell divisions. Genetics 149: 549-563.

[57] Stone SL, Braybrook SA, Paula SL, Kwong LW, Meuser J, et al. (2008) Arabidopsis LEAFY COTYLEDON2 induces maturation traits and auxin activity: implications for somatic embryogenesis. Proc. Natl. Acad. Sci 105: 3151-56.

[58] Devic M, Roscoe T (2016) Seed maturation: simplification of control networks in plants. Plant Science 252: 335-346.

[59] Honda E. Yew CL, Yoshikawa T, Sato Y, Hibara KI, Itoh JI (2018) LEAF LATERAL SYMMETRY1, a member of the WUSCHEL-RELATED HOMEOBOX3 gene family, regulates lateral organ development differentially from other paralogs. NARROW LEAF2 and NARROW LEAF3 in rice. Plant Cell Physiol 59 (2): 376-391.
[60] Li H, Xu YY, Chong K, Wang H. (2004) Analysis of transgenic Tobacco with overexpression of Arabidopsis WUSCHEL gene. Acta Botanica Sinica 46: 224-229.

[61] Wei XJ, Jiang L, Xu JF, Liu X, Liu SJ, Zhai HQ, Wan JM (2009) The distribution of japonica rice cultivars in the lower region of the Yangtze River valley is determined by its photoperiod-sensitivity and heading date genotypes. Journal of Integrative Plant Biology 51: 922-32.

[62] Park SJ, Kim SL, Lee S, Je BI, Piao HL, Park SH, Kim CM, Ryu CH, Park SH, Xuan YH, Colasanti J, An G, Han C. D. (2008) Rice Indeterminate 1 (OsId1) is necessary for the expression of Ehdl (Early heading date 1) regardless of photoperiod. The Plant Journal 56: 1018-1029.

[63] Zhao J, Chen H, Ren D, Tang H, Qiu R, Feng J, Long Y, Niu B, Chen D, Zhong T, Liu YG, Guo J (2015) Genetic interactions between diverged alleles of Early heading date 1 (Ehd1) and Heading date $3 a$ (Hd3a)/ RICE FLOWERING LOCUS T1 (RFT1) control differential heading and contribute to regional adaptation in rice (Oryza sativa). New Phytologist 208: 936-948.

[64] Xue W, Xing YZ, Weng X, Zhao Y, Tang W, Wang L, Zhou H, Yu S, Xu C, Li X, Zhang Q (2008) Natural variation in Ghd7 is an important regulator of heading date and yield potential in rice. Nature Genetics 40: 761-767.

[65] Kobayashi M, Yamaguchi I, Murofushi N, Ota Y, Takahashi N (1988) Fluctuation and localization of endogenous gibberellins in rice. Agricultural Biological Chemistry 52: 1189-1194.

[66] Yin C, Gan L, Ng D, Zhou X, Xia K (2007) Decreased panicle-derived indole-3-acetic acid reduces gibberellin A1 level in the uppermost internode, causing panicle enclosure in male-sterile rice Zhenshan 97A. Journal of Experimental Botany 58 (10): 2441-2449. DOI 10.1093/jxb/erm077.

[67] Zhu L, Hu J, Zhu KM, Fang YX, Gao ZY, He YH, Zhang GH, Guo LB, Zeng DL, Dong GJ, Yan MX, Liu J, Qian Q (2011) Identification and characterization of SHORTENED UPPERMOST INTERNODE 1, a gene negatively regulating uppermost internode elongation in rice. Plant Mol Biol 77: 475-487.

[68] Takahashi M, Nagasawa NS, Kitano H, Nagato Y (1998) panicle phytomer 1 mutation affects the panicle architecture of rice. Theoretical and Applied Genetics 96: 1050-1056.

[69] Lu H, Dai Z, Li L, Wang J, Miao X, Shi Z (2017) OsRAMOSA2 shapes panicle architecture through regulating pedicel length. Frontiers in Plant Science 8: 1538. 